\title{
Epidemiological study on Brucellosis in Azi-Kheli buffalo in district Swat Khyber Pakhtoon Khwa
}

\author{
Tariq Aziz ${ }^{1}$ Rahmatullah Rhind ${ }^{2}$, Azhar Khan ${ }^{1}$, Farmanullah ${ }^{3 *}$, \\ Rahimullah shah ${ }^{4}$, Fasisal Anwar ${ }^{5}$, Tariq Hayat ${ }^{1}$ and Saeed Sarwar ${ }^{6}$ \\ 1. Livestock and Dairy Development department KPK, Pakistan \\ 2. Department of Microbiology Sindh Agricultural University, Tandojam, Pakistan \\ 3. Faculty of Veterinary and Animal Sciences, National Center for Livestock Breeding Genetics and Genomics \\ LUAWMS, Uthal, Pakistan \\ 4. Veterinary Research Institute Peshawar, KPK, \\ 5. College of veterinary sciences, Agriculture University Peshawar, KPK, Pakistan \\ 6. Department of Animal Sciences Abdul Wali Khan University Mardan, Pakistan \\ *Corresponding author's email: farman_aup@yahoo.com,farman.vas@luawms.edu.pk \\ Citation \\ Tariq Aziz, Rahmatullah Rhind, Azhar Khan, Farmanullah, Rahimullah Shah, Fasisal Anwar, Tariq Hayat and \\ Saeed Sarwar. Epidemiological study on Brucellosis in Azi-Kheli buffalo in district Swat Khyber Pakhtoon Khwa. \\ Pure and Applied Biology. Vol. 11, Issue 1, pp291-301. http://dx.doi.org/10.19045/bspab.2022.110031

\begin{tabular}{llll}
\hline \hline Received: 24/03/2021 & Revised: 18/05/2021 & Accepted: 01/06/2021 & Online First: 30/06/2021 \\
\hline
\end{tabular}

Abstract

An epidemiological study on the seroprevalence of brucellosis in Azi-Kheli buffaloes was carried-out. The total samples studied 109 serum samples, and 100 milk samples through Rose Bengal Plate Test (RBPT), Serum Agglutination Test (SAT) and Milk Ring Test (MRT). The overall seroprevalence of brucellosis in Azi-Kheli buffaloes was recorded as 9.17, 10.09 and 10.00\% by RBPT, SAT and MRT respectively. Moreover, there were not positive sample found in male. SAT was found as the best technique for the determination antibody titer and percentage prevalence as compared to other techniques used. An area wise study was also conducted to record an epidemiological distribution which shown higher prevalence in tehsil Kabal as 11.11 and 13.33\%, in tehsils Matta 9.09 and $9.09 \%$ and in tehsil Baboozai $6.66 \%$ and $6.66 \%$ by RBPT and SAT respectively. The lowest prevalence was observed in tehsil Baboozai. Similarly, an investigation was also conducted to observe the prevalence at different lactations. The prevalence of brucellosis in sera of buffaloes in their first, second, third, fourth and fifth lactations was recorded as 5.5, 16.6, 14.2, 9.09 and $0.0 \%$ respectively. The higher prevalence was observed at second while lowest at first lactation whereas at fifth, zero prevalence was recorded. The results of current study validated that brucellosis was widespread in tehsil Kabal with a relatively and significantly higher in tehsil Kabal as compared to tehsils Matta, and tehsil Baboozai. Results of the current study may support the health care organizers to formulate suitable control plans against Brucellosis in Malakand Division.

Keywords: Azi-Kheli Buffalo; Brucellosis; MRT; RBPT; SAT

Introduction

Brucellosis is a contagious disease of domestic livestock caused by the bacteria, Brucella abortus. The disease originally transmitted to wildlife by cattle, and now is found in wild elk and buffaloes. Brucellosis is transmitted by exposure to birth materials or by ingesting infected milk [1]. Brucella species are small, Gram-negative, non-motile, non-sporeforming rods, considered being facultative 
intracellular parasites that cause chronic diseases, which usually persists for life [2]. Brucellosis is considered by the FAO and WHO as one of the most widespread zoonotic in the world [3]. The bacterium Brucella abortus is the principal cause of brucellosis in buffaloes and cattle [4]. The disease is characterised by late term abortion; infertility and reduced milk production as a result of retained placenta, secondary endometritis, excretion of the organisms in uterine discharges and milk. Full-term calves may die soon after birth. In fully susceptible herds, abortion rates may vary from 30 to $80 \%$, in some cases, abortions may be more incidentals [5].

Buffaloes mostly belong to river type breed, which are five established breeds. After few renowned buffalo breeds, the fifth breed is Azi-Kheli, which is mainly localized in the Swat valley in the North West Frontier Province (Khyber Pakhtoon Khwa).

Interestingly Pakistan is the second largest dairy buffalo country in the world [6]. and possesses the highest buffalo milk genetic potential in the world and they contribute $70 \%$ of the total milk produced in the country [7].

Farmers who rear Azikheli buffalo since long and are well aware of the breed were identified in the study area through discussion with the officials of the Department of Livestock and Dairy Development District Swat. Meeting with farmers of Azikheli buffalo were conducted for identification of Azikheli buffalo breed. Salient features of the Azikheli buffalo known in the farmers communities were brown coat colors, short tail, blue colored shining eyes, with horns bent backward and upward without twisting which differentiate it from other breed of buffalo in the country. Azikheli is a buffalo breed, in Swat, and acclimatized to the local conditions and is reared by farming communities. Home tract and study area The Azikheli is named after its original home tract known as Azikhel (Khwazakhela union council). It is an important indigenous animal genetic resource of the area and got its name from its original home tract called Azikheil, one of the several tributary valleys of river Swat. The broader home tract includes watershed of River Swat (District Swat) and River Panjkora (District Lower and Upper Dir), District Shangla, Bunair and Malakand agency. Pockets of the breed can also be found in District Mardan, Charsadda, Nowshera and Sawabi as a result of transhumant migration during winter season from upland pastures of District Swat and Dir. The Azikheli buffalo is native breed to the Hindukush Mountains of Northern Pakistan. zikhel Tehsil, the home tract of Azikheli buffalo [8].

The azikheli is known as the native breed of swat valley. The typical animals have compact body, medium sized, sickle shape horns, long and wide blade ears, characteristically short tail. Body color is albino; due to environmental changes somewhere color changes with time to light black [9].

Population estimates for this breed is based on the interviews with farmers and livestock professionals of the area. The population of Azi-Kheli buffalo is around 25,000 heads and showing a continuously decreasing trend in population. Azi-Kheli breed is equally recognized for milk and meat, but it could not cross the Swat valley. It is for the first time that Azi-Kheli buffalo has been included in the 2006 livestock census. Government farms in Pakistan have a few thousand breeding buffaloes (along with their calves and young stocks) intended for experimentation, but none of the government farms, however, has Azi-Kheli breed; as such there is no conservation programme for this breed [10]. The present study was designed to know about the epidemiological aspects of brucellosis in 
Azi-Kheli buffaloes in district Swat (Khyber Pakhtoon Khwa) on the basis of following major objectives such as to study the seroprevalence of brucellosis in Azi-kheli buffaloes in district Swat, Khyber Pakhtoon Khwa, and to compare the sensitivity of Rose-Bengal, Serum Agglutination and Milk Ring Tests for the diagnosis of brucellosis in Azi-kheli buffaloes.

The data so generated through this research will a baseline data for planning future strategies for control of brucellosis in buffaloes in Swat valley Malakand division.

\section{Materials and Methods}

The study on the seroprevalence of brucellosis in Azi-Kheli buffaloes was carried-out during year 2009 to compare the sensitivity of Rose-Bengal, Serum Agglutination and Milk Ring Tests for the diagnosis of brucellosis and to obtain a baseline data for planning future strategies for control of brucellosis in this typical buffalo breed of Swat valley.

\section{Collection of blood samples}

The animal is restrained manually. Hind leg is immobilized and slight pressure may be applied gently above the knee joint. The vein is punctured using a $20 \mathrm{G}$ needle and enough volume of blood was collected with a capillary tube or a syringe with a needle. Collection of blood specimens care as use new needle and syringe for each animal, dispose needles properly, clean the puncture area with $70 \%$ alcohol, and handle animals calmly and using appropriate restraint. A total of 100 blood samples were collected from female Azi-Kheli buffaloes and 09 samples from male buffaloes (bulls) from fifteen villages of three tehsils of district Swat. The tehsils included were Kabal, Matta and Baboozai. The blood samples from the animals were obtained by using disposable sterilized plastic syringe. On the following day, the serum was harvested in clean screw caped plastic bottles and brought to the Veterinary Research Station
(VRS), Swat and stored at $-20^{\circ} \mathrm{C}$ in deep freezer till used.

Examination of blood samples, rose bengal plate test (RBPT) antigen and control sera

The Rose Bengal stained antigen containing Brucella abortus cells (strain-99) was suspended in buffer at $\mathrm{pH} \quad 3.6$ as recommended by Veterinary Research Institute (VRI), Lahore. Before conduct of test, the antigen and serum samples were kept at room temperature to bring them to the normal physiological state. The porcelain plate wells were labeled with indelible marker according to the reference numbers of serum sample. A drop of $0.3 \mathrm{ml}$ of the serum was placed in a well of the porcelain plate. The other sera were placed in wells and labeled, using sterilized serological pipette for each sample. Similarly, positive and negative control sera were placed in last two wells of the plate. The antigen vial was shaken gently and then a drop of $0.3 \mathrm{ml}$ of antigen suspension was taken from the vial and placed near the drop of sera on the plate (both positive and negative controls). The serum and antigen were thoroughly mixed by an applicator and spread in the form of circle over an area of approximately $1.5 \mathrm{~cm}$ radius. For each serum sample a separate applicator stick used to mix the serum and antigen. The porcelain plate was then left for four minutes. The porcelain plate was then microscopically examined, using magnifying glass to record and confirm the agglutination under a good source of light against a dark background field. Due to the positive interaction between antigen and serum, the granules appeared with different intensity. The intensity showed the amount of antibodies in the serum, which indicates the specific species of bacteria in the infected animals. The result of each well was matched with positive and negative controls in the same plate before any conclusion was made. 


\section{Serum agglutination test (SAT) antigen and control sera}

The Brucella abortus agglutination concentration and phenolised suspension of Brucella abortus (strain -99) obtained from Veterinary Research Institute; Lahore was used as recommended by manufacturer. Five number sterilized test tubes were placed in a test tube rack and labeled. A $0.8 \mathrm{ml}$ solution of normal saline containing $0.5 \%$ phenol was added to the first tube and then $0.5 \mathrm{ml}$ into the remaining tubes. A $0.2 \mathrm{ml}$ of the serum to be tested was added to first tube and mixed thoroughly (1/5 dilution). A $0.5 \mathrm{ml}$ was withdrawn from first test tube and transferred into the second tube. After mixing well, $0.5 \mathrm{ml}$ was transferred to the third and so on up to the last fifth tube, where in after mixing gently, $0.5 \mathrm{ml}$ was withdrawn and discarded from last fifth tube (two fold dilution). A $0.5 \mathrm{ml}$ of the standardized Brucella abortus concentrated antigen dilution (1:20) was added to each tube containing serum dilution giving a series of final dilutions of $1 / 20,1 / 40,1 / 80$ and $1 / 160$ were then mixed thoroughly from the highest to the lowest dilution. A series of dilutions were also prepared for positive and negative sera and kept as controls. The antigen and serum were mixed well by gentle shaking and then placed in an incubator at $37^{\circ} \mathrm{C}$ for overnight. After the overnight incubation, the tubes were removed and care was taken to not disturb the agglutination. All tubes were examined using an indirect source of light against a dark background and antibody titers were recorded.

\section{Collection of milk samples}

A total of 100 milk samples were collected from the same female animals as used for obtaining blood samples. The bottles were capped tightly and brought to the laboratory of Veterinary Research Station, Swat for examination.

\section{Examination of milk samples Milk ring test (MRT), antigen and control milk samples}

Hematoxylin stained Brucella abortus (strain -99) antigen was used for Milk Ring Test as recommended by Veterinary Research Institute (VRI), Lahore. The test tubes (sterilized) were labeled and placed in the test tube rack. $1 \mathrm{ml}$ of each milk sample was drawn into each test tube, while other two test tubes were also placed in the same rack as negative and positive controls. A $0.05 \mathrm{ml}$ of Milk Ring Test stained antigen (Hematoxylin) was added to each tube by using graduated pipette. The tubes were sealed with Para-film, the antigen and samples were mixed gently and allowed to stand for about 2 minutes. Then the rack was placed in an incubator at $37^{\circ} \mathrm{C}$ for 1 hour. After the incubation, the test tubes were taken out from the incubator, examined and results were recorded as: If a deep blue colouration ring on the top of milk is formed, the test is considered to be positive. If no ring is formed on the top of milk samples, the test is considered to be negative. The results were matched with control in the same row before conclusion is to be made.

\section{Results}

The results on the seroprevalence of brucellosis in Azi-Kheli buffaloes in Swat are given in (Table 1). The RBPT was performed using the $(n=109)$ blood samples, $(n=10)$ showed agglutination and believed to be positive for brucellosis. Based on this screening, $9.17 \%$ buffaloes were found positive for brucellosis. Similarly, the SAT was also performed and $(n=11)$ out of $(\mathrm{n}=109)$ samples showed agglutination and $10.09 \%$ was recorded to be positive for brucellosis. The MRT $(\mathrm{n}=100)$ milk samples of buffaloes were examined by Milk Ring Test, $(\mathrm{n}=10)$ were found to be positive reactors for Brucella antibodies. 
The seroprevalence of brucellosis was recorded in buffaloes as $10 \%$. Generally, it seems that all the test techniques produced similar percentage of prevalence of brucellosis in Azi-Kheli buffaloes. However, SAT showed relatively higher prevalence, which was recorded as $10.09 \%$ as compared to Rose Bengal and Milk Ring Tests, both yielded 9.17 and $10.00 \%$ brucellosis in buffaloes respectively. Nevertheless, the Serum Agglutination Test (SAT) was recorded as the best technique that showed higher prevalence. While considering the sensitivity for determining of seroprevalence of brucellosis in blood samples, the Serum Agglutination Test (SAT) was found to be the best method that determined antibodies of Brucella in the sera of Azi-Kheli buffaloes.

\section{The seroprevalence of brucellosis in male} and female buffaloes

The data regarding the seroprevalence of brucellosis in male and female buffaloes are presented in (Table 1). In this survey $(n=9)$ Azi-Kheli buffalo bulls were examined by RBPT and SAT while $(n=100)$ lactating buffaloes were also investigated by RBPT and SAT techniques. Moreover, 100 milk samples were also examined by using MRT. The prevalence of brucellosis in females was recorded as 10.00, 11.00 and $10.00 \%$ by RBPT, SAT and MRT, respectively while none of the males were found to be positive for the prevalence of brucellosis in buffaloes by any of the techniques used for examination. It is concluded that prevalence of brucellosis was higher in female AziKheli buffaloes by Serum Agglutination test as compared to rest of the techniques used. Furthermore, the Serum Agglutination Test also detected some variable prevalence in females as compared to their males, because in males both the techniques Rose Bengal Plate and Serum Agglutination Tests could not detect prevalence of brucellosis in buffaloes. At the same time, milk samples from female buffaloes were collected and investigated for the seroprevalence of brucellosis and it was observed from the results given in the (Table 1), that the Milk Ring Test technique produced $10.00 \%$ brucellosis in females. It is obvious that irrespective of any techniques applied, a risk of higher prevalence of brucellosis is evident in lactating female buffaloes as compared to any other category of buffaloes investigated during present survey. On the other hand, when a comparison was made among the test techniques, Serum Agglutination Test was found to be the best technique and could be used while detecting seroprevalence of brucellosis in buffaloes.

\section{Milk ring test (MRT)}

The seroprevalence of brucellosis in buffaloes investigated at different tehsil levels.

Three tehsils i.e. Kabal, Matta and Baboozai were selected to determine the seroprevalence of brucellosis in Azi-Kheli buffaloes. The data regarding the seroprevalence of brucellosis in buffaloes at different tehsils are presented in (Table 2). In tehsil Kabal, 46 buffaloes were examined by RBPT and SAT techniques, 5 samples were found to be positive for brucellosis when examined by RBPT technique; while 6 samples were found positive for seroprevalence of brucellosis investigated by using SAT technique. The prevalence of brucellosis was recorded as 11.11 and 13.33 $\%$ by RBPT and SAT techniques, respectively. The higher seroprevalence of brucellosis was detected by Serum Agglutination Test as compared to rest of the techniques used.

Therefore, serum agglutination Test is considered to be best the technique and could be used for detecting brucellosis in buffaloes. In tehsil Matta, 33 buffaloes were examined by RBPT and SAT techniques. Of the examined samples, 3 samples were found to be positive for brucellosis using 
RBPT technique and equally 3 samples were found positive for brucellosis using SAT technique. The sero-prevalence of brucellosis recorded in buffaloes was 9.09 and $9.09 \%$ by RBPT and SAT techniques respectively. However, the equal seroprevalence of brucellosis was detected in buffaloes by Rose Bengal Plate Test and Serum Agglutination Test; both tests could be used for reliable detection of brucellosis in buffaloes. In tehsil Baboozai, the blood samples from30 Azi-Kheli buffaloes were examined by RBPT and SAT techniques. Of the samples examined, 2 were found to be positive for brucellosis by RBPT technique; however, 2 samples were found positive for brucellosis by using SAT technique. The prevalence of brucellosis was recorded as 6.66 and $6.66 \%$ by RBPT and SAT techniques respectively. It is observed that both the tests could be used for reliable detection of seroprevalence of brucellosis in buffaloes. It is clear from the results that the seroprevalence of brucellosis in Azi-Kheli buffaloes was higher in tehsil Kabal i.e. 11.11 and $13.33 \%$ by RBPT and SAT techniques respectively as compared to 9.09 and $6.66 \%$ seroprevalence of brucellosis in tehsils Matta and Baboozai by using RBPT and SAT techniques respectively. However, a lower seroprevalence of brucellosis in buffaloes was recorded in tehsil Baboozai.

The seroprevalence of brucellosis in milk samples of Azi-Khili buffaloes investigated at different tehsil level. In tehsil Kabal, 41 milk samples collected from Azi-Kheli buffaloes were investigated by Milk Ring Test (MRT) technique. Of the samples examined, 5 samples were found to be positive for brucellosis while 29 milk samples collected from the buffaloes from Matta Tehsil, 3 were found to be positive for brucellosis by using MRT technique. Whereas 30 milk samples collected from the buffaloes from Baboozai Tehsil, 2 were found positive for brucellosis (Table 2). The results further showed that the seroprevalence of brucellosis in milk samples of Azi-Kheli buffaloes were higher in tehsil Kabal i.e., 12.195 as compared to 10.34 and $6.67 \%$ seroprevalence of brucellosis in tehsil Matta and tehsil Baboozai respectively. Therefore, the highest seroprevalence of brucellosis was recorded in buffaloes of tehsil Kabal while lowest in tehsil Baboozai of Swat district Khyber Pakhtoon Khwa (Table 2). A total of 100 blood samples from Azi-Kheli breed during different lactations were taken and examined by using different techniques. At first lactation, 36 samples were tested, 2 were found positive and the prevalence was recorded as $5.55 \%$; while in $2^{\text {nd }}, 3^{\text {rd }}$ and $4^{\text {th }}$ lactations, 5, 3, and 1 sample were found positive and the prevalence was recorded as 16.66, 14.28 and $9.09 \%$, respectively. While at $5^{\text {th }}$ lactation, 2 samples were obtained and all were found negative. However, the higher prevalence of brucellosis was recorded at 2 nd lactation as compared to other lactations (Table 3).

The mean antibody titers of brucellosis in the sera of Azi-Kheli buffaloes

During present serological study positive sera samples were examined using Serum Agglutination Test (SAT) to determine Brucella antibody titer and results are shown in (Table 4). Eleven sera of positive reactors of buffaloes were titrated. Of the sera from buffaloes examined, $08(72.72 \%)$ and 3 $(27.28 \%)$ showed a titer of $1 / 20$ and $1 / 40$, respectively. No interaction between antibody and antigen was observed at the titers of $1 / 80$ and $1 / 160$ in both male and female buffaloes and considered to be without antibody or may be having the antibodies in the least numbers that did not interact with antigen and demonstrated as negative for the Brucella antibodies. However, it is concluded that brucellosis is the evident in the area with maximum and 
relatively higher prevalence and high antibody titer in females.

Table 1. The seroprevalence of brucellosis and sex-wise seroprevalence in Azi-Kheli buffaloes

\begin{tabular}{|c|c|c|c|c|c|c|}
\hline Techniques used & $\begin{array}{c}\text { No of } \\
\text { samples } \\
\text { examined }\end{array}$ & $\begin{array}{c}\text { No of } \\
\text { positive } \\
\text { samples }\end{array}$ & \multicolumn{4}{|c|}{ Percentage of positive samples } \\
\hline $\begin{array}{c}\text { Rose Bengal Plate } \\
\text { Test (RBPT) }\end{array}$ & 109 & 10 & \multicolumn{4}{|c|}{9.17} \\
\hline $\begin{array}{c}\text { Serum } \\
\text { Agglutination Test } \\
(\text { SAT })\end{array}$ & 109 & 11 & \multicolumn{4}{|c|}{10.09} \\
\hline $\begin{array}{l}\text { Milk Ring Test } \\
(\mathrm{MRT})\end{array}$ & 100 & 10 & \multicolumn{4}{|c|}{10.00} \\
\hline Techniques used & \multicolumn{3}{|c|}{ Female buffaloes } & \multicolumn{3}{|c|}{ Male buffaloes(bulls) } \\
\hline & $\begin{array}{c}\text { No. of } \\
\text { samples } \\
\text { Examined } \\
\end{array}$ & $\begin{array}{c}\text { No. of } \\
\text { positive } \\
\text { samples }\end{array}$ & $\begin{array}{c}\text { Percentage } \\
\text { of positive } \\
\text { samples } \\
\end{array}$ & $\begin{array}{c}\text { No. of } \\
\text { samples } \\
\text { examined }\end{array}$ & $\begin{array}{c}\text { No. of } \\
\text { positive } \\
\text { samples }\end{array}$ & $\begin{array}{c}\text { Percentage } \\
\text { of positive } \\
\text { samples } \\
\end{array}$ \\
\hline $\begin{array}{c}\text { Rose Bengal Plate } \\
\text { Test }\end{array}$ & 100 & 10 & 10.00 & 9 & 0 & 0.00 \\
\hline $\begin{array}{c}\text { Serum Agglutination } \\
\text { Test }\end{array}$ & 100 & 11 & 11.00 & 9 & 0 & 0.00 \\
\hline Milk Ring Test & 100 & 10 & 10.00 & - & - & - \\
\hline
\end{tabular}

Table 2. The seroprevalence determined by RBPT, SAT, and MRT at different tehsil levels

\begin{tabular}{|c|c|c|c|c|c|c|c|}
\hline \multirow[b]{2}{*}{$\begin{array}{l}\text { Technique } \\
\text { s used }\end{array}$} & \multicolumn{3}{|c|}{ Tehsil Kabal } & \multirow[b]{2}{*}{$\begin{array}{l}\text { Technique } \\
\text { s used }\end{array}$} & \multicolumn{3}{|c|}{ Tehsil Matta } \\
\hline & $\begin{array}{c}\text { No. of } \\
\text { samples } \\
\text { examined }\end{array}$ & $\begin{array}{c}\text { No. of } \\
\text { positive } \\
\text { samples }\end{array}$ & $\begin{array}{c}\text { Percentage of } \\
\text { positive } \\
\text { Samples }\end{array}$ & & $\begin{array}{c}\text { No. of } \\
\text { samples } \\
\text { examined }\end{array}$ & $\begin{array}{c}\text { No. of } \\
\text { positive } \\
\text { samples }\end{array}$ & $\begin{array}{c}\text { Percentage of } \\
\text { positive } \\
\text { samples }\end{array}$ \\
\hline RBPT & 46 & 5 & 11.11 & RBPT & 33 & 03 & 09.9 \\
\hline SAT & 46 & 06 & 13.13 & SAT & 33 & 03 & 09.9 \\
\hline $\begin{array}{l}\text { Technique } \\
\text { s used }\end{array}$ & \multicolumn{3}{|c|}{ Tehsil Babozai } & Tehsils & & & \\
\hline & $\begin{array}{c}\text { No. of } \\
\text { samples } \\
\text { examined }\end{array}$ & $\begin{array}{l}\text { No. of } \\
\text { positive } \\
\text { samples }\end{array}$ & $\begin{array}{l}\text { Percentage of } \\
\text { positive } \\
\text { Samples }\end{array}$ & & $\begin{array}{c}\text { Total No. } \\
\text { of milk } \\
\text { samples } \\
\text { examined }\end{array}$ & $\begin{array}{c}\text { No. of } \\
\text { positive } \\
\text { milk } \\
\text { samples }\end{array}$ & $\begin{array}{c}\text { Percentage } \\
\text { of positive } \\
\text { milk } \\
\text { samples } \\
\end{array}$ \\
\hline RBPT & 30 & 02 & 06.6 & Kabal & 41 & 5 & 12.19 \\
\hline SAT & 30 & 02 & 06.6 & Matta & 29 & 3 & 10.34 \\
\hline & & & & Baboozai & 30 & 2 & 6.67 \\
\hline
\end{tabular}


Table 3. The seroprevalence at various lactations

\begin{tabular}{|c|c|c|c|c|c|}
\hline $\begin{array}{c}\text { No. of } \\
\text { Lactatio } \\
\mathbf{n}\end{array}$ & $\begin{array}{c}\text { Total No. of } \\
\text { samples } \\
\text { examined }\end{array}$ & $\begin{array}{c}\text { No. of } \\
\text { positive } \\
\text { samples }\end{array}$ & $\begin{array}{c}\text { Percentage of } \\
\text { positive samples }\end{array}$ & $\begin{array}{c}\text { No. of negative } \\
\text { samples }\end{array}$ & $\begin{array}{c}\text { Percentage of } \\
\text { negative samples }\end{array}$ \\
\hline $1^{\text {st }}$ & 36 & 2 & 5.55 & 34 & 94.44 \\
\hline $2^{\text {nd }}$ & 30 & 5 & 6.66 & 25 & 83.33 \\
\hline $3^{\text {rd }}$ & 21 & 3 & 4.28 & 18 & 85.71 \\
\hline $4^{\text {th }}$ & 11 & 1 & 9.09 & 10 & 90.90 \\
\hline $5^{\text {th }}$ & 02 & 00 & 00 & 2 & 100 \\
\hline
\end{tabular}

Table 4. Positive reactors (\%) for Brucella antibodies observed by serum agglutination test

\begin{tabular}{|c|c|c|c|c|c|c|c|c|c|}
\hline & Total & \multicolumn{8}{|c|}{ Positive reactors (Titres/ Dilutions) } \\
\cline { 3 - 10 } Sex of & positive & $\mathbf{1 / 2 0}$ dilution & \multicolumn{1}{|c|}{$\mathbf{1 / 4 0}$ dilution } & \multicolumn{1}{|c|}{$\mathbf{1 / 8 0}$ dilution } & \multicolumn{2}{|c|}{$\mathbf{1 / 6 0}$ dilution } \\
\cline { 3 - 10 } animals & reactors & No. & $\mathbf{\%}$ & No. & \% & No. & \% & No & \% \\
\hline Female & 11 & 8 & 72.72 & 3 & 27.28 & 0 & 0 & 0 & 0 \\
\hline Male & 9 & 0 & 0 & 0 & 0 & 0 & 0 & 0 & 0 \\
\hline
\end{tabular}

\section{Discussion}

In the present study, seroprevalence of brucellosis was examined in Azi-kheli buffaloes of Swat (Khyber Pakhtoon Khwa) using Rose Bengal Plate Test (RBPT) and Serum Agglutination Test (SAT) for 109 blood samples and Milk Ring Test (MRT) for 100 milk samples. During the study 9.17\% brucellosis prevalence was detected by RBPT indicating seroprevalence and $10.09 \%$ by SAT. However, the studies conducted by [11]. who detected antibodies against Brucella abortus in the serum samples that ranged from 55.2-68.1\% respectively, while [12] reported the prevalence of brucellosis that ranged from 1 to $57 \%$ at different buffalo farms. In the present study, SAT was used and found to be the best method in determination and identification of antibody titers in the sera of Azi-Kheli buffaloes effectively. The positive reactors for Brucella antibodies determined by MRT technique showed that of the 100 samples examined, 10 were found to be positive for reactors of Brucella antibodies. Considerable research conducted by different authors throughout the world on the similar aspects, [13] isolated more than
$20 \%$ prevalence of Brucella from milk samples belonged to Brucella abortus by MRT. [14] reported seroprevalence of 20.3\% related to the presence of Brucella infection. [15] compared the sensitivity and specificity of RBPT, SAT and A-B ELISA techniques and revealed that the sensitivity of RBPT $(88.46 \%)$ was higher as compared to SAT $(46.15 \%)$, while specificity of SAT $(98.31 \%)$ was slightly higher than RBPT $(97.75 \%)$. The overall seroprevalence of brucellosis was found to be $12.7 \%$ and it increased with the age of animal. [16] who was reported $31 \%$ seropositivity in water buffaloes. In the present study, the seroprevalence of brucellosis was recorded as $10 \%$ in buffaloes by MRT. The seroprevalence of brucellosis in females was recorded as 10, 11 and $10 \%$ by RBPT, SAT and MRT respectively while none of the males were found to be positive for brucellosis by any of the techniques used during present study. These results are in concurrence with those of [17] who examined buffalo calves for prevalence of Brucella abortus and reported that the rate of decline of titres in heifers observed by SAT was much slower than in the calves. 
Vaccination with a half dose of Brucella abortus did not appear to offer any advantage in terms of disappearance of SAT titers. Similarly, [18] tested serum samples and reported that RBPT technique is cheaper, easier to perform, more convenient and gave correct results as compared to ELISA. In similar kind of investigation, [19] identified seropositive animals to bovine brucellosis and out of 7296 and 7169 serum samples examined; the seroprevalence was recorded as $2.61 \%$ and $2.06 \%$ respectively. [20] reported $17 \%$ of the samples were found positive for Brucella abortus antibodies. However, results of the present study are not in line to the results of the [21] who investigated the prevalence of brucellosis as $37.38 \%, 36.45 \%$ and $40.18 \%$ in animals positive for antibodies against Brucella was higher obtained by RBPT, SAT and A-B ELISA respectively. Likewise, [22] screened-out 481 buffaloes from various government farms and reported $2.91 \%$ buffaloes with brucellosis as determined by RBPT at government farms, whereas $23.70 \%$ buffaloes infected by Brucella spices at private livestock farms detected by SAT. In another study, on the similar aspects, [23] examined blood samples for Brucella antibodies by RBPT, SAT and ELISA, 35.30\%, 32.92\% and $39.45 \%$ buffaloes were found positive respectively.

Positive sera were examined to determine Brucella antibody titer, 08 (72.72\%) and 3 (27.28\%) samples showed titers of $1 / 20$ and $1 / 40$, respectively. No interaction between antibody and antigen was observed at the titers of $1 / 80$ and 1/160 in both male and female buffaloes and considered to be without antibody or may having the antibodies in the least numbers that did not interact with antigen and demonstrated as negative for the Brucella antibodies. However, it is concluded that brucellosis is the evident in the area with maximum and relatively higher prevalence and high antibody titer in females. These results coincide with the findings of [24] who investigated brucellosis in buffaloes and of the 250 animals tested, $2 \%$ showed positive reaction. Another study carried-out by [25] who reported the overall prevalence of antibodies to Brucella abortus were 12.2 and $41.9 \%$ in individual cattle and farms, respectively. True rate based on the age seroprevalence profile was estimated at 3.2 per 100 cattle years-risk. Using random effect logistic regression model as an analytical method, feeding cottonseed cake, sex, source of animals and levels of exotic blood were found to be associated with seropositivity to Brucella abortus. During present survey, the higher prevalence of brucellosis was detected in buffaloes at second lactation while lower was observed at fist lactation. In scientific literature no such information was available to compare the present results to other workers because no such kind of study has been carried out by any workers before.

From the present study, it is concluded that the brucellosis is prevailing in the female buffaloes of the area as determined by different techniques. However, no brucellosis was detected in the males. The bacterial species Brucella abortus was identified as the only species causing brucellosis in animals. The higher incidence (11\%) of brucellosis was recorded by Serum Agglutination Test (SAT). The serum antibody titer of Brucella abortus was also determined which interacted with antigen at dilutions 1:20 and 1:40, however beyond these dilutions, no interaction between antigen and serum antibody was observed. It was also concluded that the SAT technique is highly specific, sensitive and relatively more accurate in determining brucellosis in animals as compared to Rose Bengal Plate and Milk Ring Tests which sometimes produced false results. It is also 
observed that the prevalence of brucellosis was higher at second lactation as compared to other lactations. Keeping in view the above results, the author suggests the following measures to be adopted for the control of brucellosis in Azi-Kheli buffaloes. The Azi-Kheli buffaloes may be serological investigated further and comparisons should be made with other breeds of Swat district for the prevalence of brucellosis and the suspected animals should be separated and recommended for culling and slaughter. When dealing with brucellosis, the veterinarian should adopt all measures regarding brucellosis so as to avoid the infection in other animals. A proper awareness to the people of the area is needed regarding brucellosis in animals and infection related risk factors to human health, and its economical losses.

Data availability

The data used to support the findings of this study are included within the article.

\section{Authors' contributions}

Conceived and designed the experiments: $\mathrm{T}$ Aziz \& R Rhind, Performed the experiments: $\mathrm{T}$ Aziz, A Khan \& R Shah, Analyzed the data: T Aziz, Farmanullah \& F Anwar, Contributed materials/ analysis/ tools: T Aziz, S Sarwar \& T Hayat, Wrote the paper: T Aziz, R Rhind, A Khan, Farmanullah \& R Shah.

\section{Acknowledgements}

I express sincere thanks to our Research Team/Group for their kind collaboration and assistance. Special thanks to Professor Dr. Rahmatullah Rhind for their supervision and guidance. I am also very grateful to the coauthors for their critical and technical improvement of our manuscript.

\section{References}

1. Shririma GM (2009). Brucellosis review in Tanzania, prevalence, diagnostic and control challenges, Cent. Vet. Lab. Report.

2. Young EJ (1995). An overview of human brucellosis. Clin Infect Dis 21(2): 283-89.
3. Zowghi E, Ebadi A \& Mohseni B (1994). Isolation of Brucella organisms from milk of seronegative cows. Revi Sci Tech Office Inter Des Epizooties 9(4): 1175-1178.

4. Karimuribo ED, Ngowi HA, Swai ES \& Kambarage DM (2007). Prevalence of brucellosis in crossbred and indigenous cattle in Tanzania, Livestock Res. Rural Develop 19(10): 203-208.

5. Martins HBG, Bastuji F, Lima L, Flor A, Fonseca P \& Boinas F (2009). Eradication of bovine brucellosis in the Azores, Portugal-Outcome of a 5-year programme based on test-and-slaughter and RB51 vaccination. DRDA, Vinha Brava, Angra do Heroísmo 9700-861.

6. Ferreira AC, Cardoso R, Travassos I, Mariano I, Belo A, Rolao I, Manteigas A, Fonseca A \& Correa MI (2003). Evaluation of a modified rose bengal test and an indirect enzyme-linked immunosorbent assay for the diagnosis of Brucella melitensis infection in sheep. Vet Res 34: 297-305.

7. Khan MA \& Niamatullah M (2010). Buffalo versus cattle? Let us close this controversy and concentrate on improving the productivity of buffalo. Proc of the 9th Worl Buff Cong Argent pp. 1043-1045.

8. Khan MA (2009). Buffalo the animal of future. 1st, (Edi). Published by Idara Matbuaat-e-Sulemani.

9. Momen K, Muhammad S, Rahim IU, Hamayun K, Ali G, Saeed A, Mohammad S, Qaisar A \& Farmanullah (2014). Assessment of morphometric, productive and reproductive characteristics of Azikheli Buffalo in Swat valley in Northern Pakistan. Life Sci J 11(12s).

10. Sohail AK, Muhammad SK, Younas M, Shoaib S, Fida M, Sajjad A K \& Ghulam J (2009). On-Farm Performance of AziKheli Buffalo. Pak J Zoo 9 (Suppl Ser): 209-212.

11. Khan MS, Ahmad N \& Khan MA (2007). Genetic resources and diversity in dairy buffaloes of Pakistan. Pak Vet J 27(4): 201-207. 
12. Genc O, Otlu S, Sahin M, Aydn F \& Gokce HI (2005). Seroprevalence of brucellosis and leptospirosis in aborted dairy cattle and buffaloes in Turkey. Turk Vet Hay Der 29(2): 359-366.

13. Keekstra DA (2009). Efficacy of control measures against Brucellosis in the central region of Tanzania. Annu. Report, the Central Veterinary Laboratory, Ministry of livestock Development and Fisheries, Dar es Salaam, Tanzania.

14. Samar G, Aminian N, Vahdani F, \& Zowghi E (1996). A survey on human brucellosis in Iran. Archives of Razi Institute 46(47): 17-26.

15. Ndengu M, Matope G, Garine WDE, Tivapasi M, Scacchia M, Bonfini B \& Pfukenyi DM (2017). Seroprevalence of brucellosis in cattle and selected wildlife species at selected livestock/wildlife interface areas of the Gonarezhou National Park, Zimbabwe. Prev Vet Med 146: 158165.

16. Singh SV, Stephen BJ, Singh M, Gupta S, Chaubey K, Sachan TK, \& Hemati Z (2016). Comparison of newly standardized 'latex milk agglutination test', with 'indigenous milk ELISA'for 'on spot'screening of domestic livestock against Mycobacterium avium subsp. paratuberculosis infection.

17. Borriello G, Capparelli R, Bianco M, Fenizia D, Alfano F, Capuano F, Ercolini D, Parisi A, Roperto S \& Iannelli D (2006). Genetic resistance to Brucella abortus in the water buffalo, Bubalus bubalis. Infect \& Immun 74(4): 21152120.

18. Afzal M, Ashraf M \& Jahangir M, (2000). Seroprevalence of brucellosis in faisalabad. Rev Sci Tech Int Epi 19(3): 867-870.

19. Rathore BS, Barman TK, Singh KP, Singh R \& Mehrotra ML (2002). Microbiological and epidemiological studies on brucellosis in an organized herd and rural cattle and buffaloes of Uttar Pradesh. Ind J Comp Micro Immun \& Infect Dis 23(2): 195-196.

20. Orden JL (2003). Brucellosis in two departments of buenos aires province, argentina. Revista-de-med, Vet Buenos 84(5): 200-203.

21. Adguzel A, Gulluce $M$ \& Algur OF (2004). Detection of Brucella abortus specific antibodies with ELISA in raw milk samples collected in some villages of Erzurum. Turk J Infect 18(2): 187-191.

22. Barbuddhe SB, Chakurkar EB, Bale MA, Sundaram RNS \& Bansode RB (2004). Prevalence of brucellosis in organized dairy farms in Goa region. Ind J Anim Sci 74(10): 1030-1031.

23. Nasir AA, Parveen Z, Shahand MA, Rashid M (2004). Seroprevalence of brucellosis in animals at government and private livestock farms in Punjab. Pak Vet J 24(3): 144-146.

24. Trangadia B, Rana SK, Mukherjee F \& Srinivasan VA (2010). Prevalence of brucellosis and infectious bovine rhinotracheitis in organized dairy farms in India. Trop Anim Heal \& Prod 42(2): 34549.

25. Amin KMR, Rahman MB, Kabir SMI, Sardar SK \& Akand MSI (2004). Serological epidemiology of brucellosis in cattle and buffaloes of Mymensingh districts of Bangladesh. J Anim \& Vet Adv 3(11): 773-775. 